\title{
Sahne Sanatları Öğrencilerinin Yaratıcılık Kavramına İlişskin Metaforik Algıları
}

\section{The Metaphoric Perception of Performing Arts Students About Creativity}

\author{
Yunus Emre GÜMÜŞ ${ }^{1}$ (D), Özlem BELKIS² (1)
}

${ }^{1}$ Arş. Gör, Dokuz Eylül Üniversitesi, Güzel Sanatlar Fakültesi, Sahne Sanatları Bölümü, İzmir, Türkiye

${ }^{2}$ Doç.Dr., Dokuz Eylül Üniversitesi, Güzel Sanatlar Fakültesi, Sahne Sanatları Bölümü, İzmir, Türkiye

ORCID: Y.E.G. 0000-0002-2707-5366;

Ö.B. 0000-0001-6124-3506

\section{Sorumlu yazar/Corresponding author: Yunus Emre GÜMÜŞ, \\ Dokuz Eylül Üniversitesi, Güzel Sanatlar Fakültesi, Sahne Sanatları Bölümü, İzmir, Türkiye \\ E-posta/E-mail: yegumus@gmail.com \\ Başvuru/Submitted: 06.07.2021 \\ Ilk Revizyon/Revision Requested: 29.11.2021 Son Revizyon/Last Revision Requested: 29.11.2021 \\ Kabul/Accepted: 29.11.2021 \\ Online Yayın/Published Online: 07.12.2021}

Atıf/Citation: Gumus, Y.E., \& Belkis, Ö. Sahne sanatları öğrencilerinin yaratıcılık kavramına ilişkin metaforik algıları. Konservatoryum Conservatorium, 8(2), 179-201. https://doi.org/10.26650/CONS2021-963338 öz

Yaratıcılık kavramı farklı disiplinlerin uygulama alanlarında kendine çeşitli şekillerle yer bulsa da doğası gereği sanat eğitiminin merkezinde yer almaktadır. Bir kavramın başka bir kavramla ifade edilmesi sürecini içeren metafor kullanımı ise başlı başına yaratıc bir yeniden üretim sürecidir. Bu nedenle bu araştırma, sahne sanatları öğrencilerinin "yaratıcılık" kavramına ilişkin algılarını metaforlar aracılığıyla belirlemeyi amaçlamaktadır. Bu bağlamda, araştırma kapsamında öğrencilerden "Yaratıcılık...... gibidir. Çünkü.........." sorusunu doldurmaları istendi. Nitel araştırma modeline sahip olan araștırmada fenomenolojik tasarım kullanılmıştır. Araştırma Türkiye'deki Devlet ve vakıf üniversitelerinin güzel sanatlar, konservatuar ve sanat-tasarım fakültelerinde lisans eğitimi almakta olan 151 öğrenciyle gerçekleştirilmiştir. Öğrenciler "yaratıcılık" için 74 metafor ürettiler ve bu metaforlar 3 başlık altında 11 kategori altında toplandı. Metaforlar arasında en çok bahsedilen kavramlar özgürlük, okyanus / deniz, macera, rüya, ağaç / orman ve hamurdur. Metaforların ayrıştığı noktalar literatürdeki gibi yaratıcılığa ilişkin farklı yaklaşımların olduğunu göstermektedir. Metaforların ortaklaştığı noktalar da içsel yaratıcılık mitine işaret etmektedir. Araştırma sonuçları, öğrencilerin yaratıcılık kavramına ilişkin olumlu algılara sahip olduğunu ortaya koymuştur. Araştırma sonucunda olumlu görüşleri pekiştirmek ve olumsuz yargıları ortadan kaldırmak için eğitim programında bazı değişiklikler yapılması gerektiği ortaya çıkmıştır. Ayrıca araştırmanın bulguları kavramsal olarak yaratıcılığın belirli sistemler dahilinde öğretilebilir, belirli yöntemler kullanılarak geliştirilebilir olduğu düşüncesinden hareketle oluşturulacak bir müfredata ihtiyaç duyulduğunu da düşündürmektedir.

Anahtar Kelimeler: Yaratıcılık, Sahne Sanatları, Tiyatro Eğitimi

\section{ABSTRACT}

Although the concept of creativity is used in a multidisciplinary area, it is naturally in the center of art education. The use of metaphors, which includes the process of expressing a concept with another concept, is a creative reproduction process. Thus, this research aims to determine the perceptions of performing arts students regarding the concept of "creativity" through metaphors. In this regard, students were asked to complete a prompt "Creativity is like ... because ... " Using the qualitative research method, this study employs a phenomenological design. The study was carried out with 
151 fine arts faculties, conservatories, arts, and design faculties students who study at either state or foundation universities. Students produced 74 metaphors for "creativity," which were grouped under 11 categories under three titles. Among the metaphors, the most frequently mentioned ones are freedom, ocean/sea, adventure, dream, tree/forest, and dough. The study reveals that students have positive perceptions regarding the concept of creativity. Thus, it was concluded that some changes should be made in the education program to reinforce positive opinions and eliminate negative judgments.

Keywords: Creativity, Performing Arts, Theater Education

\section{EXTENDED ABSTRACT}

\section{Introduction}

Creativity is at the center of art production processes and art education (San, 2010). It is seen that creativity-related studies are done in a small number in the field of plastic arts, but rarely in the field of performing arts education. Metaphor is the expression of a concept or situation through another concept or situation, using language as a symbolic tool (Abrams \& Harpham, 2015). In recent years, the metaphorical approach research has received attention as a research strategy that has yielded highly good results by encouraging participants to engage in a natural creative thinking process by asking them to produce metaphors for a certain subject.

It can be thought that the views of performing arts students on creativity affect not only their educational success but also their professional careers. For this reason, it seems that there is a need to examine the field closely and determine the needs of field. The purpose of this phenomenological research is to examine and understand the perceptions of the performing arts students regarding the concept of creativity through metaphors.

\section{Method}

This study was designed as a phenomenological study within the qualitative approach and the data were collected through metaphors.

The study group comprises volunteers who are undergraduate performing arts students of the fine arts faculties, conservatories, and art-design faculties of eight state and three private universities in Turkey. They were reached randomly through purposeful sampling. Ninety two women (61\%) and 59 men (39\%) participants continue their education in various classes in the programs of dramatic writing, acting, stage design, theater theory, and art criticism.

In this study, data were collected using a semi-structured form. The data collection tool consists of two parts: demographic information and metaphorical question form. The 
demographic information form consists of questions about the demographic characteristics of the participants, including their university, department/program, class, and gender. The metaphoric question form consists of the following semi-structured statement, in which the participants will reveal their metaphorical perception about the concept of creativity: "Creativity is like ... because..."

During data preparation, the data in the digital survey tool (Google survey) were converted into PDF files for coding with a software program (NVivo), and then, into excel files for manual coding. These data, which were filed and prepared, were read simultaneously by two researchers, and the data were found to be repeated or left unfinished were removed from the data set.

\section{Results and Discussions}

When the findings are analyzed as a whole, it was seen that students' perceptions of creativity were mostly positive ( $88 \%$ ), and the metaphors they used were mostly ( $84 \%)$ tangible. In addition, the students used a wide range of meanings for the metaphors they used to explain creativity, but half of the students (50\%) associated creativity with nature and $28 \%$ with myth and imagination.

In the context of meaning value, majority of the students (58\%) evaluated creativity positively, whereas a considerable portion $(41 \%)$ expressed it with metaphors that have negative meanings. Based on these results, it is suggested that approaches that will reinforce the positive perception of educators of creativity in art education need to be developed. Students should be able to use the creative process more efficiently by using a series of mental techniques and methods based, especially in in-class activities where instant creativity is active. For this, it can be suggested that the educator follows the current literature and bravely tries experimental educational applications.

The findings of the study show that metaphors are largely linked to external conditions in the context of meanings and their contents. This is consistent with Amabile (1998), who stated that waiting for pleasant conditions to emerge is the killer of creativity. Emphasizing that environmental conditions are mostly preventive rather than supportive, Amabile argues that loving and challenging the work done, rather than external pressures determine the individual's motivation. 
Creativity in art education is constantly at the center both in the production and the application processes. In the field of art, it is customary to perceive creativity in a mysterious and divine dimension. This point of view not only constitutes one of the biggest obstacles to the development of creativity but turns creativity into an element that eliminates the sources of motivation. As a result, the educator's and student's conceptual perceptions of creativity are critical in performing arts education. In this context, the study's findings highlight the need of education planning, in which information regarding the definition and development methods of creativity in performing arts education would be transmitted. 


\section{Giriş}

Yaratıcılık farklı disiplinlerin çalışma alanlarına konu olan çok yönlü bir kavramdır. Bunun yanında yaratıcılık kavramı, güzel sanatlar alanındaki üretim süreçlerinin merkezinde örtük ya da açık şekilde sürekli olarak yer almaktadır. Öyle ki 20. Yüzyılın başından bu yana sanat eğitimi kavramı, genel anlamda sanatın tüm alt başlık, biçim ve alanlarını kapsayacak şekilde, okul içi ve okul dışı yaratıcı sanatsal eğitimi tanımlamak için kullanılmaktadır. Yaratıcı sanatsal eğitimin kuramsal ve yöntemsel temellerinin araştırılması sanat eğitim kuramının sorumluluk alanına girer (San, 2010). Bu bağlamda sanat eğitimi ve sanat kuramının başlangıçtan beri sanatın/sanat eğitiminin normatif, kural koyucu, yönüne yoğunlaştığı, uygulama alanında yer alan yaratıcılığa yönelik çalışmaları ihmal ettiği söylenebilir. Dahası tarihi boyunca sanat eğitiminin, süreci rasyonelleştirmek ad1na büyük çaba harcadığı bu bağlamda yaratıcılığg mistik bir boyutta değerlendirerek dışladığı da söylenebilir. Aslında sanat eğitiminde önemli bir parametre olan yaratıcıl1ğın uygulamalı atölyelerden teorik derslere kadar tüm müfredata yayılmış olması, bu çerçevede çeşitli deneysel ve kuramsal araştırmalarla desteklenmesi beklenir.

Yaratıcılık kavramı uzun süre bilinmez ve açıklanamaz gizemli bir fenomen olarak kabul edilmiş olsa da bugün günlük yaşantımıza sirayet eden her türlü bilişsel faaliyetimizin belirleyicisi olduğu kabul görmektedir. 1950 yılında Guilford'un çağrısı üzerine psikoloji alanında çeşitlenen, özellikle 1960 yıllardan itibaren artış gösteren, araştırmalar yaratıcılık kavramını tanımlanabilir ve belirli sistemler dahilinde geliştirilebilir bir bilişsel yetenek olduğunu ortaya koymuştur (Terman, 1916; Guilford, 1950; Treffinger, 1986; Torrance, 1988). 1950’lerde başlayıp 1960’ larda hız kazanan ilk araştırma dalgası "yaratıcı birey" üzerine yoğunlaşırken 1980'lerdeki ikinci dalga "yaratıcı süreç” başlığına mercek tutarak deneysel bilişsel psikolojiye dümen kırmıştır. 1990'lardaki üçüncü dalganın özellikleri ise multidisipliner yaklaşımları benimseyip sosyokültürel alana odaklanmasıdır. Dördüncü dalga için kesinleşmiş bir süreçten bahsetmek mümkün olmasa da bugün yaratıcılık çalışmalarının sinirbilim alanında yoğunlaştığı gözlemlenmektedir (Sawyer, 2006).

Uzun süre güzel sanatlar alanına hapsedilen yaratıcılık kavramı bugün psikolojiden fen bilimlerine, sanayiden iktisada, eğitimden teknolojiye kadar birçok disiplinin çalışma sahasına konuk olmaktadır. Yaratıcılık kavramı farklı disiplinlerin çalışma alanlarına konu olması nedeniyle birbirinden farklı yaklaşımlar aracılığıyla farklı tanımlar ve an- 
lamlar kazanmıştır. Yaratıcılık kavramındaki bu epistemolojik sapmalar üzerinde uzlaşılan ortak bir yaratıcılık tanımının oluşmasını engellemiştir. Bu noktada yaratıcılığın onu yönlendiren düşünce yapısına göre yeniden biçim alan organik yapısı dikkat çekicidir. Geniş anlamıyla yaratıcılık kavramının II. Dünya savaşından bu yana üzerinde en çok araştırma yapılan alanlardan biri olduğunu söyleyen Rauquette; Lowenfeld, Torrance, Maslow, Taylor, Helson ve Wallas gibi alanın önemli araştırmacılarının kavrama ilişkin farklı yaklaşım ve kategori biçimleri olsa da toplumun onlardan en iyi şekilde yararlanabilmeleri için yaratıc bireyleri yeteri derecede güvenli ve kesin bir biçimde saptayabilmenin ortak amaçları olduğunu aktarır (Rouquette, 2007).

Yapılan literatür araştırması yaratıcılık bağlamlı çalışmaların sanatın belirli alanlarında az sayıda da olsa yapıldığını, fakat sahne sanatları eğitimi alanında neredeyse hiç ele alınmadığını göstermektedir (Çellek, 2003; Dikici, 2006; Ülger, 2015). Diğer taraftan günümüzde eğitim bilimleri alanında alternatif düşünme ve etkin öğrenme gibi yaratıc1lık merkezli yöntemlerin gittikçe popüler hale geldiğini ve çağdaş eğitim müfredatının içeriğini de yönlendirdiğine tanık olunmaktadır. Ayrıca belirli bir kavramın metaforlarla ifade edilmesi aracılığıyla katılımcıyı doğal bir yaratıcı düşünme sürecine iten metaforik yaklaşım araştırmaları da son yıllarda eğitim bilimlerinde oldukça etkin sonuçlar doğuran bir araştırma yaklaşımı olarak dikkat çekmektedir. Bu bağlamda yaratıcılık kavramının yaratıcılığın odakta olduğu bir eğitim sürecinde yaratıcı bir yöntemle ele alınması dikkate değerdir.

Metafor kavramı da yaratııılık kavramı gibi farklı disiplinlerin çalı̧̧ma alanına dahil olup farklı şekillerde yorumlanarak kullanıldığı alana özel anlamlar kazanmıştır. Son yıllarda özellikle sosyal bilimler ve eğitim bilimlerinde metaforlar üzerine yapılan çalı̧sma sayısı artsa da kavramı sadece mecaz, ödünçleme, benzetme boyutunda ele alan çalışmalar tam olarak metaforik düşünceyi yansıtmamakta, bu nedenle doğrudan metafor kavramının kullanıldığı çalışmaların tercih edildiği görülmektedir (Güneş, 2019). Metafor, dilin sembolik bir araç olarak kullanılarak bir kavram ya da durumun başka bir kavram ya da bir durum aracılığıyla ifade edilmesidir (Abrams ve Harpham, 2015). Lakoff ve Johanson (2015) doğaları itibarıyla kavramsal olduğu ve en önemli anlama araçlarımızdan olduğunu belirterek metaforların dilden ziyade bir düşünce sürecinin ürünü olduğunu savunurlar. Metaforların bir görme biçimi olduğunu savunan Morgan (1994) da benzer şekilde metaforların dünyayı algılayış biçimimizle ilintili olduğunu vurgular. Son yıllarda sosyal bilimler alanında metaforik araştırmaların yoğunlaştığ 1 , belirlenmiş 
bir fenomen hakkında duygu ve algıların öğrenilmesi için verimli biçimde kullanıldığı kaydedilmektedir (Limon ve Durnal1, 2018).

Metafor en yalın ifadesiyle bir olay, durum veya nesneyi ifade etmek için başka bir nesne, durum veya olayın araç olarak kullanılmasıdır. Fakat burada söz konusu olan basit bir benzetmeden ziyade bireyin verili kavramı kendi düşünsel evreninde yorumlayıp yeniden üretmesi, ifade etmesi sürecidir. Bu noktada metaforu kullanan kişinin sosyolojik ve ideolojik tüm özellikleri bu düşüncenin yeniden üretilmesi sürecinde belirleyici rol oynar. Düşüncenin farklı bir uzamda yeniden üretilmesi süreci olarak metaforlar basit birer söz sanatından çok daha fazlasıdır.

Bireyin düşünme tarzı hakkında önemli ipuçları veren metaforların dil ve bilim hayatı üzerinde olduğu kadar günlük yaşantıda bireyin kendisini ifade etmesi üzerine de biçimlendirici bir etkisi vardır (Güneş, 2019). Metaforun gündelik hayatta sadece dilde değil düşünce ve eylemde de yaygın olduğunu keşfeden Lakoff ve Johnson insanın düşünme süreci büyük ölçüde metaforik olduğunu ileri sürer (Lakoff ve Johanson, 2015). Bu bağlamda metafor kullanımı nitel çalışmalarda bireyin belirli konulardaki algısının ortaya konulması için etkili bir araç olarak dikkat çekmektedir.

Son yıllarda özellikle eğitim bilimlerinde ve sosyal bilimleri alanında metaforların bir bilgi toplama aracı olarak kullanıldığı çalışmalara rastlanır. "Eğitim bilimlerinde veri toplama aracı olarak kullanılan metaforlar genelde nitel araştırmalar içerisinde kullanılmakta ve veri toplanan popülasyonun metafor formunda yer alan kavram hakkındaki algılarını ortaya çıkarmada bir araç görevi görmektedir" (Kılcan, 2019, s. 89). Bu çalışmaların ortak noktası hakkında daha fazla bilgi edinilmek istenen bir kavramın metaforlarla ifade edilerek incelenmesini kapsamalarıdır. Bunu yanında metaforlar yeteri kadar anlaşılmamış konuların daha iyi anlaşılmasında, problemlerin net olarak ifade edilmesinde ve düşüncelerin özetlenmesinde işlevsel birer araç olarak kullanılmaktadır (Güneş, 2019).

Sahne sanatları eğitiminde lisans öğrencilerinin yaratıcılık kavramına ilişkin görüşlerinin sadece eğitim sürecindeki başarılarını değil mezuniyet sonrası profesyonel kariyerlerini de etkileyen bir nitelikte olduğu söylenebilir. Bu nedenle yaratıcı düşünme teknik ve süreçlerinin sanat eğitimi veren kurumların müfredat içeriklerine çeşitli formlarda dahil edilmesi gerekmektedir. Bunun için de sahayı yakından inceleyerek mevcut tabloyu ve ihtiyaçları belirleyecek çalışmalara ihtiyaç duyulmaktadır. Bu bağlamda sahne sanatları alanında lisans eğitimi alan öğrencilerin yaratıcılığa ilişkin algılarının belirlenmesi önemli yer tutmaktadır. 


\section{Araştırmanın Amacı}

$\mathrm{Bu}$ fenomenolojik araştırmanın amacı sahne sanatları eğitimi alan öğrencilerin yaratıcılık kavramına ilişkin algılarının niteliğini metaforlar aracılığıyla incelemek ve anlamaktır. Araştırmanın sonuçları çerçevesinde belirlenen ihtiyaçlar aracılığıyla sahne sanatları eğitiminin ihtiyaçlarının belirlenmesi, alana özgü eğitim iyileştirmeleri için öneriler sunulması da araştırmada hedeflenmiştir.

\section{Araştırmanın Önemi, Sayıltı ve Sınırları}

$\mathrm{Bu}$ araştırma gerek yöntem gerek amaç ve bağlam açısından alanda bir ilk olma özelliği taşımaktadır. Araştırmanın sonuçları doğrultusunda, sahne sanatları eğitimi alan öğrencilerin yaratıcıllığa ilişkin bilgi ve yargılarını olumlu yönde değiştirmelerine yönelik öneriler sunulmuştur. Araştırma çerçevesinde hazırlanan ankete gönüllü olarak katılan öğrencilerin önyargısız, özverili ve tarafsız bir şekilde çalışmaya destek verdikleri, düşüncelerini yaratıcı metaforlarla ifade ederek görüşlerini paylaştıkları varsayılmaktadır. Bu araştırma Türkiye'deki lisans düzeyinde sahne sanatları eğitimi alan öğrencilerin görüşlerine odaklanmış, ayrıca Türkiye üniversitelerindeki konservatuar ve güzel sanatlar fakültelerinin Sahne Sanatları ve Tiyatro bölümleri altındaki dramatik yazarlık, dramaturji, oyunculuk, sahne tasarım, tiyatro eleştirmenliği, tiyatro kuramı dallarında eğitim gören öğrencilerle sınırlandırılmıştır.

\section{Yöntem}

$\mathrm{Bu}$ araştırmada nitel araştırma yöntemi, fenomenoloji deseninde kullanılmıştır' ${ }^{1}$. Nitel araştırma farklı araştırma desenlerini ve bunlara uygun olarak tasarlanıp kullanılan veri toplama yöntemlerini içeren bir şemsiye kavramdır. Creswell "nitel araştırma ne zaman kullanılmalı?" sorusunu "bir problem veya konunun keşfedilmesi gerektiği için" şeklinde yanıtlar; ona göre bu keşif, bir grupta kolaylıkla ölçülemeyen bilgiye ulaşma veya susturulmuş sesleri duyma ihtiyacındandır (2016, s. 47-48). Bizim araştırmamızda da keşfedilmeye çalışılan, öğrencilerin yaratıcığa ilişkin algılarıdır. Bu algıyı doğrudan sorarak değil, imgesel ve metaforik olarak tarif etmelerini bekleyerek, böylece kendi doğallığı içinde anlamak amacında olduğumuz için nitel araştırma yöntemi kullanıyoruz.

1 Bu çalışmaya Dokuz Eylül Üniversitesi Sosyal ve Beşerî Araştırma ve Yayın etik Kurulunun 31.05.2021 tarihli toplantısında alınan 23 sayılı kararla etik açıdan uygunluk verilmiştir. (Sayı: E-87347630-640.99-68986) 
Genel olarak bakıldı̆̆ında nitel araştırmaların amacı, özel bir sosyal durumu, olayı, grubu veya etkileşimi anlamaktır (Locke, Spirduso, ve Silverman, 2014). Durum çalışması, gömülü kuram, anlatı araştırması, fenomenolojik araştırma, etnografik araştırma gibi desenlerde, bu desenlerin doğasına uygun olarak belirlenen odak ya da veri toplama gibi bileşenlerde farkl1lıklar gösteren nitel araştırma yöntemi, meselelerin özüne yönelik nedensel bir kavrayışı amaçlar. Öğrencilerin yaratıcılık kavramına ilişkin algılarını üretecekleri metaforlar aracılığıyla incelemeyi amaçlayan bu çalışma fenomenolojik bir desene ihtiyaç duymuştur. Çünkü fenomenoloji çalışmaları belirli zaman ve bağlam çerçevesinde bireylerin çevresini, olayları ve durumları nasıl algıladıklarını incelemek için tasarlanmış bir araştırma desenidir (Bloor ve Wood, 2006). Burada amaç, öğrencilerin yaratıcıllk kavramını tanım ve örneklerle anlatmalarını sağlamak değil, onların bu kavrama ilişkin duygu, düşünce ve algılarını anlamaktır. Akyol'un (2019) ifadesiyle "bir işin içyüzünü görmeyi” sağlayan metaforlar burada bir araştırma aracı olarak kullanılmıştır.

Nitel bulguların analizinde ve iletiminde kullanılan metaforlar bu çalışmada bilgi toplama ve sorgulama aracı olarak kullanılmıştır. Bu çerçevedeki bir çalışmada metaforların incelenmesi, araştırmacıya iki yönlü bir zenginlik sunmaktadır. İlki, katılımcıların ürettikleri metaforların değeridir; çünkü metafor, bireylerin genel olarak dünyayı kavrayışlarına sinen düşünce ve görme biçimlerini formüle eden zihinsel araçlardır (akt.: Güneş, 2019) ve bu şekilde katılımcıların algıları hakkında tek bir sözcükle derin bir bilgi alanı iletmelerini sağlar. İkinci olarak araştırmacıların okuyucuya ilettikleri metaforların değeridir; Patton (2014) metaforların nitel araştırmacıların okuyucularıyla güçlü bağlantı kurmalarının, ayrıca bulguları iletmenin güçlü bir yolu olduğunu belirtmektedir, bu şekilde toplanan verilerin okuyucuyla hem duygu hem kavrayış bakımından en verimli şekilde paylaşılmasını sağlar.

\section{Katılımcilar}

Bu araştırmada Türkiye'deki Devlet ve vakıf üniversitelerinin güzel sanatlar, konservatuar ve sanat-tasarım fakültelerinde sahne sanatları/tiyatro alanında lisans eğitimi almakta olan öğrencilerden gönüllü olarak araştırmaya katılanlar, çalışma grubu olarak belirlenmiştir. Araştırmaya ilişkin soru formu şu üniversitelerde eğitimlerini sürdüren öğrenciler tarafından gönüllü olarak doldurulmuştur: Dokuz Eylül Üniversitesi, Uludağ Üniversitesi, Atatürk Üniversitesi, Bahçeşehir Üniversitesi, Süleyman Demirel Üniversitesi, Maltepe Üniversitesi, İstanbul Üniversitesi, Ordu Üniversitesi, Ankara Üniversitesi, Doğuş Üniversitesi. 
92 Kadın (\%61) ve 59 Erkek (\%39) katılımcı, dramatik yazarlık, oyunculuk, sahne tasarımı, tiyatro kuramı ve eleştiri ana sanat dallarında çeşitli sınıflarda eğitimlerine devam etmektedirler. Tablo 1'de de gösterildiği gibi toplam 151 katılımcının 85 'i oyunculuk, 56's1 dramatik yazarlık / dramaturgi, 8'i sahne tasarımı, 2'si ise tiyatro kuramı üzerine eğitim almaktadırlar.

Tablo 1. Katılımcıların Eğitim Aldıkları Anasanat Dalları

\begin{tabular}{|l|c|c|}
\hline & Katılımcı sayısı & Oran \\
\hline Oyunculuk & 85 & $\% 56$ \\
\hline Dramatik Yazarlık / Dramaturgi & 56 & $\% 37$ \\
\hline Sahne Tasarımı & 08 & $\% 5$ \\
\hline Tiyatro Kuramı & 2 & $\% 1$ \\
\hline Toplam & 151 kişi & \\
\hline
\end{tabular}

Ayrıca Tablo 2'de de gösterildiği gibi 151 katılımcıdan 44'ü (\%29) birinci sınıf, 36's1 (\%24) ikinci sınıf, 34’ü (\%23) üçüncü sınıf, 30’u (\%20) dördüncü sınıf ve 6’sı (\%4) da beș ve daha üstü sınıflarda eğitimini sürdürmektedir. Tablo 3 'te sunulan katılımcıların yaş demografilerine bakıldığında ise en büyük oranla $62(\% 41)$ katılımcının 22-26 yaş aralığında, $44(\% 29)$ katılımcının 18-22 yaş aralığında, $30(\% 20)$ katılımcının 26-30 yaş aralığında, 10 (\%7) katılımcının 30-34 yaş aralığında, 5 (\%3) katılımcının ise 34 yaşın üzerinde olduğu görülmektedir.

Tablo 2. Katılımcıların sınıf düzeyleri

\begin{tabular}{|l|c|c|}
\hline & Katılımcı sayısı & Oran \\
\hline Sinıf & 44 & $\% 29$ \\
\hline Sinıf & 36 & $\% 24$ \\
\hline Sinıf & 34 & $\% 23$ \\
\hline Sinıf & 30 & $\% 20$ \\
\hline Sinıf ve üzeri & 06 & $\% 4$ \\
\hline Toplam & 151 kişi & \\
\hline
\end{tabular}

Tablo 3. Katılımcıların yaşları

\begin{tabular}{|l|c|c|}
\hline & Katılımc sayısı & Oran \\
\hline $18-22$ yaş aralı̆̆ & 44 & $\% 29$ \\
\hline $22-26$ yaş aralığ1 & 62 & $\% 41$ \\
\hline $26-30$ yaş aralığı & 30 & $\% 20$ \\
\hline $30-34$ yaş aralığ & 10 & $\% 7$ \\
\hline 34 yas üzeri & 5 & $\% 3$ \\
\hline Toplam & 151 kişi & \\
\hline
\end{tabular}




\section{Veri Toplama Araçları}

Araştırmanın verileri, yarı yapılandırılmış bir form aracılığı ile toplanmıştır. Veri toplama aracı iki bölümden oluşmaktadır: demografik bilgi formu, metaforik soru formu.

\section{Demografik Bilgi Formu}

Bu bölüm, katılımcıların eğitim gördükleri üniversite, bölüm/anasanat dalı, sınıf ve cinsiyet olmak üzere demografik özelliklerinin öğrenilmesine yönelik sorulardan oluşmaktadır:

\section{Metaforik Soru Formu}

Bu bölüm, katılımcıların yaratıcılık kavramıyla ilgili metaforik algıyı ortaya koyacaklar1 yarı yapılandırılmış şu ifadeden oluşmaktadır: "Yaratıcılık gibidir, çünkü................."

\section{İşlem}

Soru formu, Google Anketler aracılığıyla hazırlanıp sahne sanatları eğitimi veren üniversitelerin bölüm ya da dal başkanı öğretim üyelerine ulaşılarak öğrencilere iletilmesi istenmiştir. Bu bağlamda katılımcılar amaçlı örnekleme yoluyla rasgele ulaşılmış kişilerden oluşmaktadır.

İnternetin bilimsel araştırmalarda gittikçe daha geniş bir veri toplama zemini olarak kullanılması, 2019 Mart ayından itibaren yaşanan COVID-19 pandemisi nedeniyle veri toplamanın neredeyse olanaksızlaşması, bu araştırmada da verilerin dijital araçlarla toplanmasını zorunlu kılmıştır. İnternet yoluyla veri toplamanın, Coulson'un (2016) da belirttiği ulaşılması zor kitlelere ulaşma, düşük maliyetler, katılımcılara daha kolay erişim, araştırmacı anonimliği gibi potansiyel avantajları ile katılımcı anonimliği ve aldatma, düşük tepki ve yanıt oranları, araştırma ortamı üzerinde kontrol kaybı, uyarıcı sınırlılıkları, teknik sorunlar gibi potansiyel zorlukları bu araştırmanın veri toplama sürecinde de yaşanmıştır. Ancak geleneksel yollarla yapılan araştırmalarda uyulan tüm etik ilkelere, bu araştırmanın veri toplama sürecinde de uyulmuştur.

\section{Verilerin Analizi}

$\mathrm{Bu}$ araştırma için üç aşamalı bir çözümleme yapılmıştır: hazırlık, çözümleme (decoding), kodlama (encoding). 
Verilerin hazırlanması aşamasında dijital anket aracındaki (Google Survey) veriler manuel kodlama yapmak üzere excell, yazılım programı (NVivo) ile kodlama yapmak üzere pdf dosyalarına dönüştürülmüştür. Dosyalanıp hazırlanan bu veriler iki araştırmacı tarafından eşzamanlı olarak okunmuş, tekrarlar ve yarım bırakılmalar saptanarak bu girdiler veri setinden çıkarılmıştır. Araştırmamızda, Coulson'un (2016) da dikkat çektiği internet üzerinden toplanan verideki en önemli sorun olarak anket tekrarı, veriler titizlikle kontrol edilerek tespit edilmiş̧ir. Bunun yanında yarı yapılandırılmış sorunun her iki tarafını da doldurmamış veya metafor oluşturmak yerine tanım ya da sıfat kullanmış katılımcıların verileri de yarım kabul edilerek setten çıkarılmıştır. Bu şekilde ilk aşamada toplanan 180 veriden 29'unun tekrar girdi olduğu saptanarak çıkarılmış, kodlamaya 151 veri alınmıştır. Araştırmanın çalışma grubu da geçersiz veriler dışarda bırakılarak sunulmuştur.

Verilerin çözümlenmesi aşamasında veriler araştırmacılar tarafından ayrı ayrı okunmuş ve incelenmiş, daha sonra bir araya gelinerek genel olarak değerlendirilmiştir. Patton'un (2014) da vurguladığı gibi verilerin düzenlenmesi ve muhtemel temaların belirmesi açısından bu hazırlık süreci önemle kullanılmıştır. Araştırmamızın bu aşamasında tümevarımsal bir analiz yapılmış, hazırlık sürecinde içerik analizi ile incelenen verideki örüntüler, tema ve kategoriler tümevarımsal bir yaklaşımla çıkarılmıştır. Üç ana tema, alt temalarıyla birlikte kategorize edilerek kodlama kitapçığı şu şekilde oluşturulmuştur: Metaforların Kavramsallı̆̆ı, Metaforların Anlam Değeri ve Metaforların Anlam İçeriği.

Verilerin kodlanması aşamasında araştırmacılar önce tek başına, işbirlikli kodlama (Saldana, 2019) yapmışlar, kodlamaları karşılaştırarak, benzerlik ve farklılıkları belirleyerek analize son halini vermişlerdir. Eşzamanlı kodlama yapılarak bir verinin birden fazla alt temada yer alabilmesine izin verilmiş, fakat her veri, alt tema bağlamında sadece bir kez kodlanmıştır. Kodlamadan sonra ifade bakımından birbirine benzeyen (örn. bulut, yağmur yüklü bulut) metaforlar birleştirilmiştir.

\section{Geçerlik Güvenirlik}

Nitel araştırmalarda geçerlik ve güvenirlik meselesi farklı yaklaşımlarla ele alınmıştır. Kimi yaklaşımlar nicel araştırmalardaki geçerlik güvenirlik ilişkisini nitel çalışmalara taşımaya çalışmışlar, kimi araştırmacılar ise nitel yöntem ve desenlere özgü farklı bir terminoloji ortaya koymuşlardır. $\mathrm{Bu}$ bağlamda nitel bir araştırmada güvenirlik, Creswell'in (2016) de vurguladığı gibi, kodlayıcılar arası görüş birliğine dayanır. Araştırmamızda da araştırmacıların kodlamadaki kararlılı̆̆ izlenmiş \%98 uyum saptanmıştır. Güvenirlik konusunda Miles ve Huberman'a (2016) göre \%80 uyum yeterlidir. 


\section{Bulgular}

Metafor, Grekçe taşımak, transfer etmek, aktarmak demek olan metaherein kelimesinden gelir (Güneş, 2019). Buradan hareketle bu çalışmada da sahne sanatları öğrencilerinin yaratıcılık kavramına ilişkin ürettikleri metaforlar kategorik bir yapıya aktarılarak sunulmuştur. Katılımcıların belirledikleri metaforların bazıları ortaklıklar gösterirken bazılarının sadece bir kişi tarafından kullanıldığı görülmüştür. Tablo.4’te bu çalışma kapsamında üretilmiş tüm metaforlar, tekrarlanma sıklıkları (f) da belirtilerek sunulmuştur.

Tablo 4. Yaratıcılık Kavramı İçin Üretilen Metaforlar

\begin{tabular}{|c|c|c|c|}
\hline METAFORLAR & f & METAFORLAR & $\mathbf{f}$ \\
\hline özgürlük & 11 & Atatürk & 1 \\
\hline okyanus / deniz / su & 11 & ateş & 1 \\
\hline macera & 8 & bisiklete binmek & 1 \\
\hline hayal / rüya & 7 & biz & 1 \\
\hline ağaç / orman & 6 & bomba & 1 \\
\hline hamur & 4 & buluş yapmak & 1 \\
\hline nefes almak / yaşamak & 4 & buz dağ1 & 1 \\
\hline bulut & 4 & çă̆ & 1 \\
\hline yemek / yemek yapmak & 4 & delilik & 1 \\
\hline keşif/ keşfetmek & 4 & doğa & 1 \\
\hline tohum & 3 & farkında olmak & 1 \\
\hline çocuk/ çocukluk & 3 & düşünme & 1 \\
\hline değerli taş & 3 & ejderha & 1 \\
\hline uzay & 3 & espri & 1 \\
\hline evren/ gökyüzü & 3 & gökkuşağ 1 & 1 \\
\hline ayna & 3 & gözkapağ1 & 1 \\
\hline y1ldiz & 3 & hiçbir şey & 1 \\
\hline enerji/ akış & 2 & hoş bütün şeyler & 1 \\
\hline sonsuzluk & 2 & idrar & 1 \\
\hline balon & 2 & ilaç & 1 \\
\hline bulmaca & 2 & ilham & 1 \\
\hline cesaret & 2 & insan & 1 \\
\hline toprak & 2 & işleyen demir & 1 \\
\hline doğum & 2 & kafamızdaki kütüphane & 1 \\
\hline uyku & 2 & kağıt & 1 \\
\hline 1ş1k & 2 & kar tanesi & 1 \\
\hline kara tahta & 1 & kum saati & 1 \\
\hline kas & 1 & kuş & 1 \\
\hline kelebek & 1 & renkli ressam paleti & 1 \\
\hline klişe & 1 & saman & 1 \\
\hline kronik hastalık & 1 & sıradan bir taş & 1 \\
\hline sonuç & 1 & ütopya & 1 \\
\hline
\end{tabular}




\begin{tabular}{|l|c|l|c|}
\hline spor araba & 1 & Van Gogh'un bir tablosu & 1 \\
\hline üretmek & 1 & varış noktası & 1 \\
\hline yalnızlık & 1 & yoga & 1 \\
\hline yemeğe atılan tuz & 1 & zehir & 1 \\
\hline yeniden var etmek & 1 & heyecan & 1 \\
\hline
\end{tabular}

Tablo 4'te de görüldüğü gibi yaratıcılık kavramını anlatmak için en çok kullanılan iki metafor özgürlük ve okyanus/deniz sözcükleri 11'er katılımcı tarafından; macera metaforu 8 katılımc1, hayal/rüya metaforu 7 katılımcı, ağaç/orman metaforu 6 katılımc1, hamur, nefes almak/yaşamak, bulut, yemek/yemek yapmak, keşif/keşfetmek metaforları 4'er katılımcı; tohum, çocuk/çocukluk, değerli taş, uzak, evren/gökyüzü, ayna, yıldız metaforları 3'er katılımc1; enerji/akış, sonsuzluk, balon, bulmaca, cesaret, toprak, doğum, uyku, 1şık metaforları 2'şer katılımcı ve kas, kelebek, klişe, kronik hastalık, sonuç, spor araba, üretmek, yalnızlık, yemeğe atılan tuz, yeniden var etmek, Atatürk, ateş, bisiklete binmek, biz, bomba, buluş yapmak, buz dağı, çağ, delilik, doğa, farkında olmak, düşünme, ejderha, espri, gökkuşağ1, gözkapağ1, hiçbir şey, hoş bütün şeyler, idrar, ilaç, ilham, insan, işleyen demir, kafamızdaki kütüphane, kağıt, kar tanesi, kum saati, kuş, renkli ressam paleti, saman, sıradan bir taş, ütopya, Van Gogh'un bir tablosu, varış noktası, yoga, zehir, heyecan metaforları da 1'er katılımcı tarafından kullanılmıştır. En çok kullanılan metaforlardaki benzerlikleri görmek açısından şu örnekler ele alınabilir:

"Yaratıcılık özgürlük gibidir, çünkü ilham bağımsızdır" (K10)

"Yaratıcılık özgürlük gibidir, çünkü sınırların dışına çıkmamıza izin verir" (K65)

"Yaratıcılık özgürlük gibidir, çünkü yaratırken sınırlar göz önünde bulundurulmaz" (K166)

"Yaratıcılık deniz gibidir, çünkü içinden zararlı yararlı mı bir şek çıkacağı belli olmaz, fakat yaratıcılığın meyveleri her zaman bir sürprize neden olur" (K21)

"Yaratıcılık derin bir deniz gibidir, çünkü ilk başka su çok soğuk gelir fakat yüzmeye başlayınca daha da derine gitmek istersiniz" (K89)

"Yaratıcılık okyanus gibidir, çünkü derinlerde ya da yüzeyde uçsuz bucaksız bir dünya sunar" (K108) 
$\mathrm{Bu}$ araştırma için toplanan veriler incelendiğinde öğrencilerin ürettikleri metaforların Tablo.5'te gösterildiği gibi Kavramsallık, Anlam Değeri ve Anlam İçeriği olmak üzere üç ana temada kategorize edilmesi mümkün olmuştur. Tablo.5 aynı zamanda, bu araştırmada ulaşılan metaforlara ilişkin büyük resmi de sunmaktadır.

Tablo 5. Sahne Sanatları öğrencilerinin yaratıcılık kavramına ilişkin ürettikleri metaforların kategorik görünümü

\begin{tabular}{|l|c|c|}
\hline KATEGORI & $\mathbf{f}^{*}$ & ORAN \\
\hline Metaforların Kavramsallığı & & $\% 56$ \\
\hline Somut & 84 & $\% 44$ \\
\hline Soyut & 67 & \\
\hline Toplam & 151 & $\% 58$ \\
\hline Metaforların Anlam Değeri & 88 & $\% 41$ \\
\hline Olumlu & 62 & $\% 1$ \\
\hline Nötr & 1 & \\
\hline Olumsuz & 151 & $\% 33$ \\
\hline Toplam & & $\% 19$ \\
\hline Metaforların Anlam İçeriği & 50 & $\% 16$ \\
\hline Doğa ile ilişkili olan & 28 & $\% 13$ \\
\hline Mistik ve düşsel olan & 24 & \\
\hline İnsan bedeni ve eylemleriyle ilişkili & 24 & \\
\hline Kavramla ilişkili & 20 & \\
\hline İnsanın ürettikleriyle ilişkili & 5 & \\
\hline Bireyle ilişsili olan & 151 & \\
\hline Toplam & & \\
\hline
\end{tabular}

* f: frekans, tekrarlanma sıklı̆̆ 1

Tablo.5'te görüldüğü gibi 151 metaforun kavramsal olarak 84'ü (\%56) somut ve 67'si (\%44) soyut olarak değerlendirilmiştir. Katılımcıların oluşturdukları somut metaforlara ağaç, ayna, su, deniz, okyanus, bulut, tohum, ışık, yakut, ilaç, kelebek, nefes almak, doğum yapmak, bisiklete binmek, yıldız, oyun hamuru, ressam paleti, elmas, yakut örnek olarak sunulabilir. Soyut metaforlar içinse özgürlük, macera, hayal, çocukluk, sonsuzluk, cesaret, uyku, sonuç, ütopya, kafamızdaki kütüphane, delilik örnekleri burada anılmalıdır. Yaratıcıllğı anlatmak için kullanılan somut ve soyut metaforlar şöyle örneklenebilir:

"Yaratıc1lık Van Gogh'un bir tablosu gibidir, çünkü kimin ne düşüneceğini umursamadan özgün olanı ve içinden geleni yansıtmayı bilir.” (K47)

"Yaratıcılık kum saati gibidir, çünkü azaldığı sanılsa da bir tarafı hep dolar." (K59)

"Yaratıc1lık sonsuzluk gibidir, çünkü yok olmaz, kaybolmaz, görünmez tükenmez." (K61) 
“Yaratıcılık enerji gibidir, çünkü açığa çıkınca fark edilir.” (K94)

Tablo.5'te sunulan 151 metafor anlam değeri olarak incelendiğinde ise 88 'inin (\%58) olumlu, 62'sinin (\%41) nötr, 1'inin (\%1) ise olumsuz olduğu bulgulanmıştır. Bu çalışmada yaratıcılık kavramını olumsuzlayan tek bir metafor "yaratıcılık spor araba gibidir, çünkü çok yakar” (K63) ifadesiyle dikkat çekici olmuştur. Büyük bir bölümü olumlu değer taşıyan metaforlar için şu örnekler sunulabilir:

“yaratıcılık derin nefes almak gibidir, çünkü var olan soruna çözüm bulunmuştur." (K14)

“yaratıcılık yakut gibidir, çünkü hem değerlidir hem de zor bulunur.” (K32)

“yaratıcılık maceraya atılmak gibidir, çünkü belli bir sınırı yoktur ve ilerledikçe çeşitlenir, genişler.” (K51)

“yaratıcılık kum saati gibidir, çünkü azaldığı sanılsa da hep bir tarafı dolar." (K59)

Yaratıcılık için katılımcıların ürettikleri metaforların \%58'inin olumlu olmasının yanında \%41'nin nötr olması da dikkat çekici olmuştur. Olumlu ya da olumsuz bir algı taşımayan bu nötr metaforlara şu ifadeler örnek olarak verilebilir:

“yaratıcılık ressam paleti gibidir, çünkü her renk bir şey ifade edebilir ya da karışan renkler bir anlam oluşturabilir.” (K71)

“yaratıcılık oyun hamuru gibidir, çünkü istediğin şekli verebilirsin.” (K49)

"yaratıcılık su gibidir, çünkü su hayatın kaynağıdır, yaratıcılık ise sanatın." (K30)

“yaratıcılık uyku gibidir, çünkü insanı ne zaman ziyaret edeceğine kendisi karar verir.” (K29)

Araştırmada toplanan veriler kategorize edilip ayrıştırılırken en ayrıntılı bölüm, metaforların Anlam İçeriği bölümü olmuştur. Tablo.5’te görüleceği gibi katılımcıların yaratıcıl1ğ1 anlatmak için ürettikleri metaforların anlam içerikleri altı temada kodlanmıştır. Bunlardan 50 metafor doğa ile ilişkili olan hayvan (kelebek, kuş), bitki (ağaç, tohum), evren - gökyüzü (yıldız, uzay, gökyüzü, deniz, okyanus, bulut, buzdağı), doğa olayları ve maddelere (su, ateş, toprak, 1şık, tuz, altın, elmas, yakut) işaret eden metaforlardır. Kısaca, 
araştırmaya katılan toplam 151 katılımcının \%33’ü yaratıcılık için doğa ile ilişkili kavramları metafor olarak seçmiştir ve buna ilişkin şu örnekler sunulabilir:

"yaratıcılık kelebek gibidir, çünkü bir mucizenin uçması için kanat olur.” (K3)

“yaratıcılık kuş gibidir, çünkü uçsuz ve bucaksız yerlere götürür sizi.” (K115)

"yaratıcılık ağaç gibidir, çünkü kökleri sağlam, göklere uzanan, dalları özgür, bezen yaprak döken ama bir damla suyla bile hayat bulup yeşeren bir yapı.” (K106)

"yaratıcılık tohum gibidir, çünkü çok suladığınızda değil, doğru suladığınızda, aydınlığın ve karanlığın dengesinde ve her zaman geceleri filizlenip çiçek açar." (K112)

“yaratıcılık uzay gibidir, çünkü sonsuzdur ve kendi içinde genişler." (K15)

"yaratıcılık yıldız gibidir, çünkü her zaman vardır fakat bazen kendini ilk bakışta göstermeyebilir.” (K28)

“yaratıcılık kar tanesi gibidir, çünkü kişiyi eşsiz kılar." (K158)

"yaratıcılık elmas gibidir, çünkü üzerine gidildikçe, tozu temizlendikçe daha da parlar ve değerlenir." (K77)

Sahne sanatları öğrencilerinin yaratıcılık kavramına ilişkin ürettikleri metaforların Anlam İçeriğine bakıldığında ikinci büyük grup 28 (\%19) metafor ile mistik ve düşsel olan metaforlar seçimleridir. Bunlara verilebilecek örnekler şunlar olabilir:

"Yaratıcılık ejderha gibidir, çünkü hiç olmamıştır ama coğrafyalar ve nesiller boyu varlığından eminsinizdir.” (K9)

"Yaratıcılık delilik gibidir, çünkü sınırları ortadan kaldırmak gerekir." (27)

"Yaratıcılık hiç bilmediğin bir yolda yürümek gibidir, çünkü yolun sonunda ne var ve yol boyunca karşımıza ne çıkacak oraya varmadan bilemeyiz." (K44)

İnsan bedeni ve eylemleriyle ilişkili olarak üretilen metaforlar da Anlam İçeriği teması altında kodlanmıştır. Çözümlemeye dahil edilen 151 metaforun 24'ü (\%16) insan bedeni ve eylemleriyle ilişkili ifadelerdir. İnsan bedeni (kas, kronik hastalık, göz kapağı, idrar) ve eylemleriyle ilgili ifadeler (bisiklete binmek, nefes almak, uyumak, doğum yapmak, yemek yemek, buluş yapmak, yüzmek) yaratıcılık kavramının aktarılması için oldukça ilginç seçimler gibi görünmektedir ve şöyle örneklenebilirler: 
"Yaratıcılık kas gibidir, çünkü çalıştıkça kuvvetlenir.” (K12)

"Yaratıcılık kronik hastalık gibidir, çünkü bireyin parçasıdır ve birey dünyayı onsuz algilayamaz." (K75)

"Yaratıcılık bisiklete binmek gibidir, çünkü öğrenilip geliştirilebilir ve bizi mükemmel yolculuklara çıkaran bir yol arkadaşıdır.” (K8)

"Yaratıcılık uykuya dalmak gibidir, çünkü yaratımın saf hali, gerçeklik filtresinden geçmemiş rüyalar gibidir.” (K176)

Katılımcıların yaratıcılık kavramını metaforla açıklarken kullandıkları anlam içeriklerinin 24'ü (\%16) da bir kavramla ilişkilidir. Metafor olarak bir kavram seçen katılımcıların macera, sonuç, süreklilik, yalnızlık, klişe, sonsuzluk, bilinç/sizlik, özgürlük ifadelerini seçtikleri görülmektedir. Bunları veri setindeki tam ifade halleriyle örneklemek gerekirse:

“Yaratıcılık yaşam gibidir, çünkü sen var olduğun sürece devam eder.” (K131)

"Yaratıcılık çocuk kalmak gibidir, çünkü sınırsız hayal etmekle birlikte yeni şeyler bulup onun peşinden koşmak gibidir.” (K145)

Sahne sanatları öğrencilerinin yaratıcılık kavramına yönelik ürettikleri metaforların Anlam İçeriği incelenirken 151 metafordan 20'sinin (\%13) insanın ürettikleriyle ilişkili olduğu görülmüştür. Bunlar ayna, balon, bomba, bulmaca, çağ, ilaç, kâğıt, kum saati, oyun hamuru, sanat, spor, zehir ifadeleridir şöyle örneklenebilir:

"Yaratıcılık bomba gibidir, çünkü içinde tuttuğun şeyler tetikleyici bir unsurla bir anda dışarı fışkırır." (K146)

"Yaratıcılık beyaz bir kağıt gibidir, çünkü yaratıyı ve zihin kalemimizi bekler." (K123)

"Yaratıcılık ayna gibidir, çünkü var olduğunu hissettirir.” (K78)

Katılımcıların yaratıcılık ile ilgili ürettikleri metaforlardan 5'inin (\%3) doğrudan bir grup veya bireyle ilişkili olduğu görülmüştür. Şu iki örneğin, yaratıcılığı tarifte ilginç olacağı kanısındayız:

"Yaratıcılık Atatürk gibidir, çünkü yeni fikirler geliştirebilme kabiliyetidir.” (K41)

"Yaratıcılık çocuk gibidir, çünkü onlar her şeyi en doğalıyla yakalarlar.” (K 95) 
Sahne sanatları eğitimi alan öğrencilerin yaratıcılık kavramını anlatmak için bu araştırma kapsamında kullandıkları metaforlara bir bütün olarak bakıldığında, ögrencilerin yaratıcılık kavramına ilişkin algılarının çoğunlukla (\%88) olumlu, kullandıkları metaforların yine çoğunlukla (\%84) somut olduğu görülmüştür. Bu yaklaşımları yanında öğrenciler yaratıcılık kavramını anlatmak için kullandıkları metaforlar için oldukça geniş bir anlam içeriği yelpazesi kullanmışlar, fakat öğrencilerin yarısı (\%50) bu kavramı doğa ile, \%28'i mistik ve düşsel olanlarla, ilişkilendirmişlerdir. Araştırmamızın bulguları ayrıca yaratıcılık kavramının en çok özgürlük, okyanus / deniz, macera, hayal/rüya ve ağaç/orman ifadeleriyle anlatıldığını da ortaya koymaktadır.

Burada aktarılan bulgular, bu araştırmaya gönüllü olarak katılan sahne sanatları öğrencilerinin yaratıcılık kavramına ilişkin ürettikleri metaforlardır, fakat genellenebilme kabiliyetine de sahiptir.

\section{Sonuçlar ve Tartışma}

Yaratıcılık literatürünün büyük bir bölümünü kavramın tanımlanma çabası oluşturur. Yaratıcıllğın neliği üzerine bugün bile tam bir uzlaşma sağlanamamış olsa de günümüzde eleştirel ve yaratıcı düşüncenin egemen olduğu bir toplum düzeni çağdaş dünyanın birincil koşulu varsayılmaktadır. Eğitim bilimleri alanında yapılan çalışmalar yaratıcı düşünme aracılığıyla öğrencilerin problem çözme becerilerinin geliştirmesine odaklanmaktadır. Diğer taraftan iktisat ve işletme alanlarında verimliliği arttırmak için yaratıcıllı̆ın kullanıldığı görülmektedir. Bu örnekler bugün yaratıcılığın sanatın bileşenlerinden biri olmaktan çıkıp bir problem çözme aracı olarak çok yönlü ve işlevsel bir kavram haline geldiğini göstermektedir.

Bireyin bilişsel haritasını oluşturan kültürel etkileşim, iletişim ve deneyim aynı zamanda farklı nedenlerle manipülasyona açık bir yapıdadır. Yaratııılık kavramına ilişkin pek çok ön yargı ya da yanlış inanış kavramın algılanması, uygulanması ve öğretilmesi süreçlerine doğrudan etkilemektedir. Metaforlar aracılı̆̆ıly ifade edilen kavramlar öğrencilerin bilişsel haritalarındaki konumu görmek açısından eğitim bilimlerinde kullanılan etkin bir yöntemdir.

$\mathrm{Bu}$ araştırma kapsamında güzel sanatlar ve konservatuarların sahne sanatları/tiyatro bölümleri altında farklı ana sanat dallarında eğitim görmekte olan toplam 151 öğrenciden "yaratıcılık" kavramına ilişkin 74 farklı metafor elde edilmiştir. Bunlar metaforların kavramsallığı, 
anlam değeri ve anlam içeriği olmak üzere 3 ana kategori altında toplanmıştır. Her kategori kendi içinde metaforların özelliklerine göre alt başlıklar altında toplanmıştır. Metaforun kavramsallığı soyut, somut; metaforun anlam değeri olumlu, olumsuz, nötr; metaforun anlam içeriği ise doğa ile, mistik ve düşsel olanla, insan bedeni-eylemleriyle, kavramla, insanın ürettikleriyle ve bireyle ilişkili olmak üzere 11 alt başlığa ayrılmıştır. Metafor kategorileri farklılıklar gösterse de sonuçlar, öğrencilerin yaratıcılık kavramını somut (f: 84/151), olumlu (f: 88/151) ve doğa ile ilişkilendirdiklerini (f: 50/151) göstermektedir.

Metaforların ayrıştığı noktalar bize tıpkı literatürdeki gibi yaratıcılığa ilişkin farklı yaklaşımların olduğunu göstermektedir. Metaforların ortaklaştığı noktalar da içsel yaratıcılık mitine işaret eden ortak bir gizem şemsiyesi altında buluşmaktadır. İçsel yaratıcılık efsanesine meydan okuyan Paul Gardiner (2016), "Oyun Yazarlı̆̆ Eğitimi Ve İçsel Yaratıcılık Efsanesi” adlı makalesinde bu bakış açısının yaratıcılığın geliştirilmesi önündeki en önemli engellerden birisi olduğuna dikkat çeker. Gardiner'e göre idealist/romantik bakış açısı yaratıcılık kavramını bilinmez, nesnel dünyanın olanaklarıyla çözümlenemez bir boyutta değerlendirme eğilimindedir. İçsel yaratıcıllı̆̆ın bir safsata olduğunu savunan Gardiner'a göre yaratıcılık doğru bir eğitim ve yönlendirmeyle geliştirilebilir.

Anlam değeri bağlamında öğrencilerin \%58'i kavramı olumlu olarak değerlendirirken \%41'i yaratıcılık kavramını olumsuz anlama gelen metaforlarla ifade etmiştir. Bu araştırmanın sonuçlarından hareketle sanat eğitiminde eğiticilerin yaratıcılık kavramına dair olumlu algıyı pekiştirecek, olumsuz algıları terse çevirecek yönde tutumların geliştirilmesi önerilmektedir. Özellikle anlık yaratıc1lığın aktif olduğu ders içi çalışmalarda beyin egzersizi temelli bir dizi teknik ve yöntemi devreye sokarak öğrencilerin yaratıcı süreci daha verimli kullanmaları sağlanmalıdır. Bunun için de eğiticilerin güncel literatürü takip edip deneysel eğitim uygulamalarını cesaretle denemekten kaçınmamaları önerilebilir.

Araştırmaya katılan öğrencilerin kavramı doğallık ve zorunluluk bağlamında yaşamsal olanla özdeşleştirmeleri dikkat çekicidir. Araştırma bulguları göstermiştir ki metaforlar anlam değeri bağlamında büyük oranda insan üretimi olan şeyler, insan yaşamı ya da onu çevreleyen doğanın etrafinda toplanmaktadır. Bu bağlamda yanıtlar literatürde önemli bir başvuru kaynağı olan Csikszentmihalyi'nin yaratıcılığa dair görüşlerinden izler taş1maktadır. Csikszentmihalyi yaratıcılığın tekil bir anda, parlayan fikirlerde gizli olmadığını, çok yönlü, çok bileşenli bir sürecin ürünü olduğunu savunur. Tutku, mutluluk, uzmanlık, merak ve özgürlük gerektiren bir süreçtir bu (Csikszentmihalyi, 1996). 
Araştırmanın bulguları metaforların anlam içeriği bağlamında büyük oranda dışsal koşullara bağlandığını göstermektedir. Bu tablo yaratıcılığın ortaya çıkması için konforlu koşulların oluşmasını beklemenin yaratıcılığın katili olduğunu söyleyen Amabile'in (1998) görüşleriyle denk düşmektedir. Amabile'e göre yaratıcılık deneyim, yetenek ve yaratıcı düşünce sürecinin bir ürünüdür. Çevresel koşulların çoğunlukla destekleyici olmaktan çok engelleyici olduğunu vurgulayan Amaible yine de bireyin motivasyonunu dış baskılardan çok yapılan işi sevmenin ve meydan okumanın belirlediğini savunur.

Sanat eğitiminde yaratıcılık kavramının gerek fikrin üretim aşamasında gerekse de üretilen fikrin uygulanma sürecinde sürekli olarak merkezde yer aldığını söyleyebiliriz. Sanat alanında özerk ve özel bir alan sağladığı varsayımıyla yaratıcılığın gizemli ve tanrısal bir boyutta algılanması alışılagelmiş bir durumdur. Bu bakış açısı yaratıcılığın geliştirilmesi önündeki en büyük engellerden birini oluşturmakla kalmayıp motivasyon kaynaklarını ortadan kaldıran bir unsura dönüşmektedir. Bu nedenle sahne sanatları eğitiminde de eğiticinin ve öğrencinin yaratıcılığa dair kavramsal algısı büyük önem taş1maktadır. Bu bağlamda öğrencilerin yaratıcılık algılarını metaforlar aracılığıyla ifade ettikleri bu araştırmanın bulguları sahne sanatları eğitiminde yaratıcılığın tanımı, geliştirilme yöntemlerine ilişkin bilginin merkezde olduğu bir eğitim planlamasının gerekliliğine işaret etmektedir. Bu planlama teorik ve uygulama süreçlerinin tümüne yayılacak şekilde öncelikle öğrencilerin yaratıcılığa dair sahip olduğu ön yargıları ortadan kaldıracak şekilde uygulanmalıdır.

Ayrıca araştırmanın bulguları kavramsal olarak yaratıcılığın belirli sistemler dahilinde öğretilebilir, belirli yöntemler kullanılarak geliştirilebilir olduğu düşüncesinden hareketle oluşturulacak bir müfredata ihtiyaç duyulduğunu da düşündürmektedir. Sadece yaratıc1lğın aktif olduğu uygulama derslerinde değil kuramsal derslerin işlenişi sürecinde de eğitim materyallerinin kullanımından dersin sunumuna kadar geniş bir yelpazede yaratıcı öğretim yöntemlerinden faydalanılması önerilmektedir. Bunun yanında sahne sanatları öğrencilerinin yaratıcılık algılarının ders içi motivasyonlarından mesleki bağllıklarına etkisine kadar geniş yelpazede etki alanı olduğu düşünülürse yaratıcıllğın genel bir eğitim aracı olarak benimsenmesi kültürel ve toplumsal geleceğimiz açısından da belirleyici olacaktır.

Yaratıcılık, yetenek gibi tartışmalı kavramlara dair öğrenci görüşlerinin incelendiği bu tür fenomenolojik araştırmaların daha yoğun çalışılması sadece eğitimin iyileştirilmesi için değil alan literatürü açısından da oldukça etkili olacaktır. Ayrıca nitel araştırmalar 
aracılı̆̆ıyla öğrencilerin öğretim süreçlerinin planlanmasına dahil edilmesi yaratıcı düşüncenin egemen olduğu bir toplum tasarımı için atılan önemli bir adım olacaktır. Farklılaşarak zenginleşmesi her açıdan faydalı olacaktır.

Etik Komite Onayı: Bu çalışmaya Dokuz Eylül Üniversitesi Sosyal ve Beşerî Araştırma ve Yayın etik Kurulunun 31.05.2021 tarihli toplantısında alınan 23 sayılı kararla etik açıdan uygunluk verilmiştir. (Sayı: E-87347630-640.99-68986).

Hakem Değerlendirmesi: Dış bağımsız.

Yazar Katkıları: Çalışma Konsepti/Tasarım- Y.E.G., Ö.B.; Veri Toplama- Y.E.G.; Veri Analizi/Yorumlama- Ö.B., Y.E.G.; Yazı Taslağı- Y.E.G., Ö.B.; İçeriğin Eleştirel İncelemesi- Ö.B.; Son Onay ve Sorumluluk- Y.E.G.

Çıkar Çatışması: Yazarlar çıkar çatışması bildirmemiştir.

Finansal Destek: Yazarlar bu çalışma için finansal destek almadığını beyan etmiştir.

Ethics Committee Approval: Ethics committee approval was obtained with the decision numbered 23 taken at the meeting of Dokuz Eylul University Social and Human Research and Publication Ethics Committee dated 31.05.2021. (Issue: E-87347630-640.99-68986). Peer-review: Externally peer-reviewed.

Author Contributions: Conception/Design of Study- Y.E.G., Ö.B.; Data Acquisition- Y.E.G.; Data Analysis/Interpretation- Ö.B., Y.E.G.; Drafting Manuscript- Y.E.G., Ö.B.; Critical Revision of Manuscript- Ö.B.; Final Approval and Accountability- Y.E.G.

Conflict of Interest: The authors have no conflict of interest to declare.

Grant Support: The authors declared that this study has received no financial support.

\section{Kaynakça/References}

Abrams, H. M., \& Harpham, G. G. (2015). A Glossary Of Literary Terms. Delhi: Cengage Learning India Private Limited.

Akyol, C. (2019). Metaforların kullanım alanları ve faydaları. B. Kılcan (Dü.) içinde, Metafor ve Eğitimde Metaforik Çalışmalar İçin Bir Uygulama Rehberi (3. Baskı b.). Ankara: Pegem Akademi.

Amabile, T. M. (1998). How to kill creativity. Boston, MA: Harvard Business School Publishing.

Andreasen, N. C. (2017). Yaratıcı Beyin Dehanın Nörobilimi. Ankara: Akılçelen Kitaplar.

Bloor, M., ve Wood, F. (2006). Keywords in qualitative methods: a vocabulary of research concepts. London: Sage. Coulson, N. (2016). Psikologlar için çevrimiçi araştırma yöntemleri. (D. Hasta, Dü.) Ankara: Nobel Yay.

Creswell, J. (2016). Nitel Araştırma Yöntemleri (3. Baskı b.). (M. Bütün, ve S. Demir, Dü) Ankara: Siyasal Yayınları. Csikszentmihalyi, M. (1996). Creativity: Flow and the Psychology of Discovery and Invention. New York: Harper Collins. Çellek, T. (2003) Sanat ve Bilimde Yaratıcılık. Pivolka, 2(8), 4-11.

Dikici, A. (2006). Sanat eğitimi ve öğrencilerin yaratıcılık düzeyleri. Eğitim ve Bilim, 31(139).

Güneş, C. (2019). Metafor Nedir Ne Değildir? B. Kılcan içinde, Metafor ve Eğitimde Metaforik Çalışmalar İçin Bir Uygulama Rehberi (s. 1-14). Ankara: Pagem Akademi.

Gardiner, P. (2016). Playwriting pedagogy and the myth of intrinsic creativity. Publication Cover Research in Drama Education: The Journal of Applied Theatre and Performance, 247-262.

Guilford, J. P. (1950). Creativty. American Psychologist, 444-454.

Kılcan, B. (2019). Eğitim Bilimlerinde Metaforların Veri Toplama Aracı Olarak Kullanılması, Bir Örnek Uygulama. B. Kılcan içinde, Metafor ve Eğitimde Metaforik Çalışmalar İçin Bir Uygulama Rehberi (s. 89-108). Ankara: Pagem Akademi. 
Lakoff, G., ve Johanson, M. (2015). Metaforlar Hayat Anlam ve Dil. (G. Y. Demir, Çev.) Chicago: İthaki Yayınları.

Limon, İ., ve Durnalı, M. (2018). Doktora öğrencilerinin doktora eğitimi ve öğretim üyelerine yönelik metaforik algıları. Sakarya University Journal of Education, 8(1), 26-40.

Locke, L. F., Spirduso, W. W., ve Silverman, S. J. (2014). Proposal That Work; A Guide For Planning Dissertation And Grant Proposals. California: Sage Publication.

Lowenfeld, V. (1957). Creative and Mental Growth. New York: Macmillah.

Miles, M., ve Huberman, A. (2016). Nitel Veri Analizi. (S. Akbaba Altun, ve A. Ersoy, Çev.) Ankara: Pegem Akademi.

Morgan, G. (1994). Yönetim ve Örgüt Teorilerinde Metafor. İstanbul: Mess .

Patton, M. (2014). Nitel Araştırma ve Değerlendirme Yöntemleri (3. Baskı b.). (M. Bütün, ve S. Demir, Çev.) Ankara: Pegem Akademi.

Rouquette, M.-L. (2007). Yaratıclık. (İ. Yerguz, Çev.) Ankara: Dost Kitabevi Yayınları.

Saldana, J. (2019). Nitel Araştırmacılar İçin Kodlama El Kitabı. (A. Tüfekci Akcan, ve S. Şad, Çev.) Ankara: Pegem Akademi.

San, İ. (2010). Sanat Eğitim Kuramları. Ankara: Ütopya Yayınları.

Sawyer, K. (2006). Explaining Creativity: The Science of Human Innovation. New York: Oxford.

Simsek, H., ve Yıldırım, A. (2018). Sosyal Bilimlerde Nitel Araştırma Yöntemleri. Seçkin Yayıncılık.

Torrance, E. P. (1988). The nature of creativity as manifest in its testing. R. J. Sternberg içinde, The nature of creativity: Contemporary psychological perspectives (s. 43-75). Cambridge University Press.

Ülger, K. (2015). Sanat Eğitiminin Düşünme Becerileri Üzerine Etkisi. Milli Eğitim Dergisi, 45(206), $135-147$.

Wallas, G. (1926). The Art of Thought. New York: Harcourt, Brace $\S$ World. 
